ISSN 1507-3858

e-ISSN 2450-0003

\title{
Jarosław Wątróbski
}

Zachodniopomorski Uniwersytet Technologiczny w Szczecinie

e-mail: jwatrobski@wi.zut.edu.pl

\section{Paweł Ziemba}

Państwowa Wyższa Szkoła Zawodowa w Gorzowie Wielkopolskim

e-mail: pziemba@pwsz.pl

\section{ANALIZA METODYK BUDOWY ONTOLOGII ZASOBÓW INTERNETOWYCH \\ ANALYSIS OF METHODOLOGIES OF INTERNET RESOURCES ONTOLOGY DESIGN}

DOI: $10.15611 /$ ie.2015.2.05

JEL Classification: C88

Streszczenie: $\mathrm{W}$ artykule podjęto problem analizy metodyk projektowania ontologii zasobów internetowych. W tym celu na wstępie dokonano identyfikacji dostępnych metodyk budowy ontologii, takich jak: Cyc, metodyka Gruningera i Foxa, metodyka Usholda i Kinga, On-To-Knowledge, Methontology, DILIGENT, HCOME, DOGMA oraz NeOn. Następnie przeprowadzono analizę ich przydatności dla potrzeb projektowania semantycznego opisu zasobów internetowych (zawartości np. stron WWW czy też portali społecznościowych). Rozważania pozwoliły na sformułowanie zbioru wytycznych zawierającego niezbędne elementy metodyki projektowania ontologii w wyżej wymienionym obszarze. Artykuł kończą wnioski, według których dla przedstawionego problemu budowy ontologii zasobów internetowych najlepszym rozwiązaniem wydaje się zastosowanie podejścia hybrydowego, które łączyłoby elementy poszczególnych metodyk.

Słowa kluczowe: inżynieria ontologii, Semantic Web, NeOn, Methontology.

Summary: The article discusses the problem of analysis of online resources ontology design methodologies. For this purpose, the available ontology design methodologies were identified: Cyc, Gruninger \& Fox methodology, Ushold \& King methodology, On-ToKnowledge, Methontology, DILIGENT, HCOME, DOGMA and NeOn. Then an analysis of their suitability for the design of semantic description of web resources was performed (eg. website content, social networking sites, etc.). Considerations allowed to formulate a set of guidelines containing the necessary elements of ontology design methodology in the above mentioned area. The article ends with conclusions, according to which the best solution for the present problem of ontology design seems to be the use of a hybrid approach which combines elements from different methodologies.

Keywords: ontology engineering, Semantic Web, NeOn, Methontology. 


\section{Wstęp}

Aktualnie jesteśmy świadkami dynamicznego rozwoju kierunku zarządzania wiedzą. Obejmuje to nie tylko zarządzanie organizacją, lecz również różnorodne obszary związane z technologią, biologią czy socjologią. Szczególne miejsce zajmuje tutaj sieć Internet, oferująca szerokie możliwości dostępu do informacji. Obecnie Internet najnowszej generacji jest oparty na koncepcji Web 3.0, określanej często w literaturze jako sieć semantyczna (Semantic Web) [Berners-Lee i in. 2001]. Cechą różnicującą Web 3.0 jest możliwość dokonania powiązań semantycznych pomiędzy przesyłanymi danymi i ich kontekstem [Davies, Studer, Warren (red.) 2006]. Koncepcja Web 3.0, opiera się na dostarczeniu zautomatyzowanego dostępu do informacji, opartego na przetwarzanych maszynowo znaczeniach danych oraz heurystyk, które wykorzystują te metadane. Reprezentacja danych semantycznych, wspierająca teorie dziedzinowe (czyli ontologie) jest ściśle sprecyzowana, dając możliwość uzyskania nowej jakości sieci Internet [Shahabi, Chen 2003]. Oprócz oczywistych uwarunkowań technologicznych warstwę formalną i filozoficzną sieci semantycznej tworzą ontologie [Fensel 2003]. Najprościej ontologię można określić jako formalny system reprezentacji wiedzy [Gruber 1993] (KRS - Knowledge Representation System), złożony z trzech głównych elementów: klas, instancji i właściwości [Smith 2003]. Ontologia jest również określana jako specyfikacja konceptualizacji, dostarczając opisu pojęć i relacji zachodzących pomiędzy nimi [Gruber 1993]. Pozyskanie ustrukturyzowanej reprezentacji informacji przez ontologie stanowi jeden z głównych celów w związku ze zrozumieniem sieci semantycznej [Berners-Lee i in. 2001]. Jak wskazano powyżej w odniesieniu do sieci semantycznej, ontologie odgrywają kluczową rolę we wspomaganiu procesów automatyzacji podczas pozyskiwania wiedzy oraz dostępu do informacji [Hepp 2007].

Celem artykułu jest porównanie metodyk budowy ontologii dla potrzeb semantycznego opisu poszczególnych zasobów internetowych, wskazanie różnic między nimi oraz ewentualne wskazanie metodyki najlepiej przystosowanej do budowy ontologii zasobów internetowych. Należy wskazać, że proces budowy ontologii dziedzinowej winien być ukierunkowany na właściwe i pełne odwzorowanie danego obszaru wiedzy dziedzinowej. W tym zakresie niedozwolone jest traktowanie tego procesu jedynie jako sztuki czy też prostego działania inżynierskiego [Suarez-Figueroa i in. 2012]. Analiza i zastosowanie właściwych metodyk projektowania ontologii pełnią tutaj funkcję fundamentalną. Szczególnego uwzględnienia wymaga również środowisko technologiczne, które można w sposób uogólniony zdefiniować jako zasoby internetowe, obejmujące takie formy, jak np. portale internetowe, fora dyskusyjne, sklepy internetowe, portale społecznościowe, blogi czy sieci społeczne.

\section{Metodyki projektowania ontologii}

W literaturze wyróżnia się liczne metodyki budowy i projektowania ontologii. Wiele z nich jest scharakteryzowanych chociażby w pracach: [Corcho i in. 2006; Casellas 
2011; Sure i in. 2006; Fernandez-Lopez, Gomez-Perez 2002]. Najbardziej szczegółowa charakterystyka większości metodyk zawarta jest w pracy [Gomez-Perez i in. 2004]. Wśród metodyk budowy ontologii wymienić można m.in.: Cyc, metodyki Gruningera i Foxa oraz Usholda i Kinga, On-To-Knowledge, Methontology, DILIGENT, HCOME, DOGMA, NeOn oraz wiele innych.

Metodyka Cyc jest złożona z trzech etapów. Etap I polega na ręcznym kodowaniu ukrytej i jawnej wiedzy zawartej w źródłach. Odbywa się ono bez pomocy systemów przetwarzania języka naturalnego. Etap II stanowi kodowanie wiedzy przez człowieka, wspomagane przez narzędzia wykorzystujące wiedzę już wprowadzoną do bazy. Etapem III jest natomiast kodowanie wiedzy przeprowadzone przez narzędzia programowe. W fazie tej ludzie tylko wskazują źródła wiedzy i mogą wyjaśniać najbardziej skomplikowane partie tekstu. Zgodnie z metodyką Cyc w każdej fazie wykonywane są dwa zadania. Zadaniem pierwszym jest rozwój reprezentacji wiedzy i ontologii najwyższego rzędu, zawierającej najbardziej ogólne pojęcia. Zadanie drugie jest to reprezentowanie pozostałej części wiedzy za pomocą pojęć podstawowych, takich jak atrybuty i koncepty [Gomez-Perez i in. 2004; Fernandez-Lopez, Gomez-Perez 2002].

Metodyka Gruningera i Foxa inaczej nazywana jest metodyką TOVE, gdyż posłużyła ona do zbudowania ontologii o właśnie takiej nazwie [Rajpathak, Chougule 2011]. Metodyka ta pozwala zbudować logiczny model wiedzy określany za pomocą ontologii. Składa się na nią sześć etapów. I etap to identyfikacja scenariusza motywacyjnego, tj. scenariusza rozwoju aplikacji, która będzie korzystać z ontologii. Scenariusz ten opisuje zbiór wymagań, które ontologia powinna spełniać. II etapem jest sformułowanie nieformalnych pytań kompetencyjnych, na które powinna odpowiadać ontologia. Kolejnym etapem jest określenie terminologii z wykorzystaniem logiki I rzędu, a szczególnie identyfikacja obiektów (instancji) i predykatów reprezentujących koncepty, atrybuty i relacje. IV etap dotyczy sformalizowania pytań kompetencyjnych za pomocą logiki I rzędu, a etap $\mathrm{V}$ polega na określeniu aksjomatów, również z wykorzystaniem logiki I rzędu. Ostatnim krokiem jest etap VI, w którym należy określić warunki pozwalające na uznanie ontologii za kompletną [Gomez-Perez i in. 2004; Fernandez-Lopez, Gomez-Perez 2002; Gruninger, Fox 1995].

Metodyka Usholda i Kinga jest też określana jako model przedsięwzięć (Enterprise Model Approach) [Rajpathak, Chougule 2011]. Na metodykę tę składają się cztery etapy. Etap I polega na identyfikacji celu budowy ontologii, a etapem II jest sama budowa ontologii. Na etap budowy składają się trzy kroki. Krokiem 1 jest identyfikacja i zdefiniowanie kluczowych pojęć i relacji, krok 2 polega na kodowaniu pojęć i relacji do formalnego języka ontologii, a krok 3 ma na celu sprawdzenie, czy można zintegrować istniejące ontologie z tą, która jest budowana. Etapem III jest ocena ontologii pod względem technicznym, pytań kompetencyjnych i specyfikacji. Etap IV polega na określeniu wytycznych dotyczących dokumentacji ontologii zależnie od typu i celu budowy ontologii [Gomez-Perez i in. 2004; Fernandez-Lopez, Gomez-Perez 2002; Uschold, Gruninger 1996]. 
On-To-Knowledge koncentruje się na budowie ontologii z uwzględnieniem jej wykorzystania w przyszłości. Wobec tego za pomocą tej metodyki budowane są ontologie zależne od aplikacji, w których mają one być stosowane. Metodyka On-To-Knowledge składa się z pięciu etapów. Etapem I jest studium wykonywalności uwzględniające przypadki i scenariusze użycia. Etap II to rozpoczęcie procesu budowy ontologii. W wyniku tego etapu otrzymuje się wymagania dotyczące ontologii, takie jak: cel ontologii, wskazówki projektowe, konwencje nazw, źródła wiedzy, potencjalni użytkownicy i scenariusze użycia, pytania kompetencyjne, wspierane aplikacje. Innymi efektami uzyskiwanymi w tym etapie są: wstępny słownik pojęć ontologii i półformalny opis ontologii. Etapem III jest udoskonalanie, mające na celu wytworzenie dojrzałej ontologii, która jest ukierunkowana na aplikację. $\mathrm{Na}$ etap ten składają się dwa kroki: pozyskiwanie wiedzy od ekspertów dziedzinowych i formalizacja ontologii z wykorzystaniem określonego języka reprezentacji. Etap IV obejmuje ocenę ontologii, a szczególnie: sprawdzenie wymagań i pytań kompetencyjnych oraz testowanie ontologii w środowisku docelowej aplikacji. Ostatni już $\mathrm{V}$ etap budowy ontologii polega na jej utrzymaniu i rozwijaniu [Gomez-Perez i in. 2004; Casellas 2011; Sure i in. 2009].

Metodyka DILIGENT jest przedstawicielem grupy metodyk tzw. trzeciej generacji. Ma ona wspierać ekspertów dziedzinowych podczas projektowania i rozwijania ontologii w rozproszonym środowisku pracy. Na metodykę tę składa się pięć etapów. W etapie I eksperci oraz inżynierowie ontologii i wiedzy wspólnie budują początkową ontologię. Ontologię otrzymują użytkownicy, którzy w etapie II adaptują i modyfikują ją zależnie od potrzeb. W etapie III eksperci analizują modyfikacje wprowadzone przez użytkowników w ontologiach lokalnych i, zależnie od wyników analizy, decydują o wprowadzaniu ewentualnych zmian i korekt do następnej wersji ontologii. W etapie IV wprowadzane są do ontologii wcześniej ustalone korekty i zmiany, a etap V polega na aktualizacji lokalnych ontologii udostępnionych użytkownikom, aby odzwierciedlone w nich były zmiany, które zostały ujęte w etapie IV [Kotis, Vouros 2010; Pinto i in. 2009].

HCOME jest, podobnie jak DILIGENT, metodyką trzeciej generacji. Jest ona ukierunkowana na grupowe opracowywanie ontologii, przy czym w tej metodyce większy nacisk jest położony na wspólne ustalanie przez użytkowników zakresu zmian w nowej wersji ontologii. Składa się ona z trzech etapów. Etap I jest określany jako faza specyfikacji. Obejmuje on określenie zakresu i celów ontologii, dyskusję między projektantami w celu ustalenia akceptowalnej przez wszystkich specyfikacji oraz udokumentowanie ustalonej specyfikacji. Najbardziej rozbudowany jest etap II, nazywany fazą konceptualizacji, w którym każdy z członków zespołu projektantów indywidualnie opracowuje swoją wersję ontologii. W etapie tym mogą być zaimportowane istniejące ontologie ogólne, tezaurusy i zasoby domenowe, co ma pomóc inżynierom lepiej zrozumieć pojęcia dziedzinowe. Następnie rozpoczyna się proces budowy ontologii, w czym zawiera się m.in. zarządzanie wersjami ontologii, porównanie różnych wersji i identyfikacja ontologii, które mogą zostać połączone, 
oraz dołączanie do ontologii komentarzy, przykładów i szczegółowych specyfikacji. Ostatni etap obejmuje eksploatację ontologii, a szczególnie: korzystanie z nich, ocenę i krytykę przez członków zespołu projektantów oraz porównywanie różnych ontologii i wskazywanie różnic między nimi. W efekcie etapu eksploatacji powinna zostać zaproponowana nowa wersja ontologii uwzględniająca uwagi poszczególnych projektantów [Kotis, Vouros 2010; 2006].

Działania związane z zarządzaniem

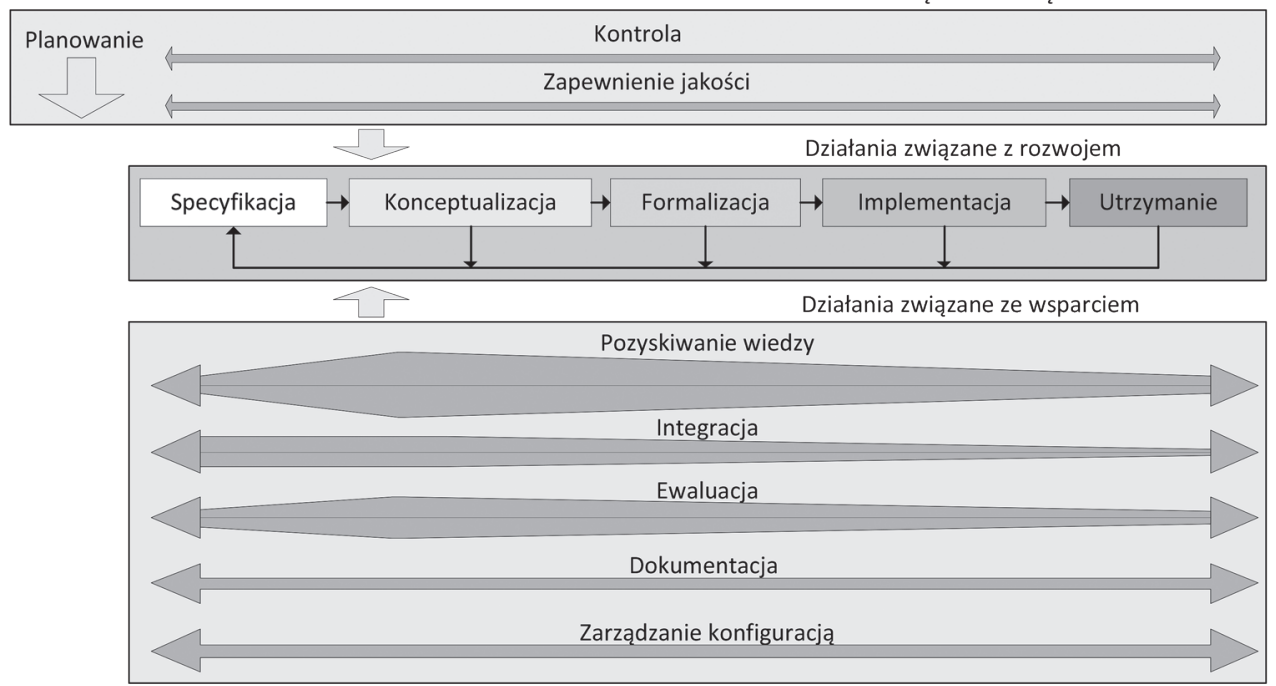

Rys. 1. Etapy i działania podejmowane w metodyce Methontology

Źródło: opracowanie własne na podstawie [Gomez-Perez i in. 2004].

W Methontology zaproponowano „cykl życia budowy ontologii” oparty na tzw. ewoluujących prototypach. Podejście to zakłada, że poszczególne etapy tej metody$\mathrm{ki}$, tj.: I. specyfikacja, II. konceptualizacja, III. formalizacja, IV. implementacja oraz V. utrzymanie, są wykonywane cyklicznie, a w każdym cyklu otrzymuje się nową wersję ontologii. Jednocześnie z tymi etapami realizowane są: kontrola i zapewnianie jakości oraz procesy wspierające, takie jak: pozyskiwanie wiedzy, integracja, ocena, dokumentacja i zarządzanie konfiguracją. W metodyce tej bardzo rozbudowany jest etap konceptualizacji, na który składa się aż 11 zadań. Zadaniem 1 jest budowa słownika terminów, które będą zawarte w ontologii, ich definicji w języku naturalnym, synonimów i akronimów. Zadanie 2 obejmuje budowę taksonomii pojęć, a zadanie 3 koncentruje się na budowaniu ad hoc diagramów relacji binarnych pomiędzy pojęciami. Efektem zadania 4 jest słownik pojęć zawierający instancje pojęć, atrybuty klas $\mathrm{i}$ ich relacje. Słownik ten jest podstawą do realizacji kolejnych zadań. Zadanie 5 polega na szczegółowym opisaniu binarnych relacji ad hoc, występujących w diagramach 
i słowniku. Zadaniem 6 jest szczegółowe opisanie atrybutów instancji występujących w słowniku pojęć, a zadanie 7 polega na opisaniu atrybutów klas zawartych w słowniku. Z kolei zadanie 8 dotyczy opisania stałych. Gdy pojęcia, taksonomie, atrybuty i relacje są zdefiniowane, należy zrealizować zadanie 9 , tj. opisać aksjomaty formalne, oraz zadanie 10, którym jest opisanie reguł. Ostatnie już zadanie 11 polega na zdefiniowaniu instancji [Gomez-Perez i in. 2004; Fernandez-Lopez, Gomez-Perez 2002; Corcho i in. 2005]. Kolejne etapy i działania wspierające w ramach metodyki Methontology zawarto na rys. 1.

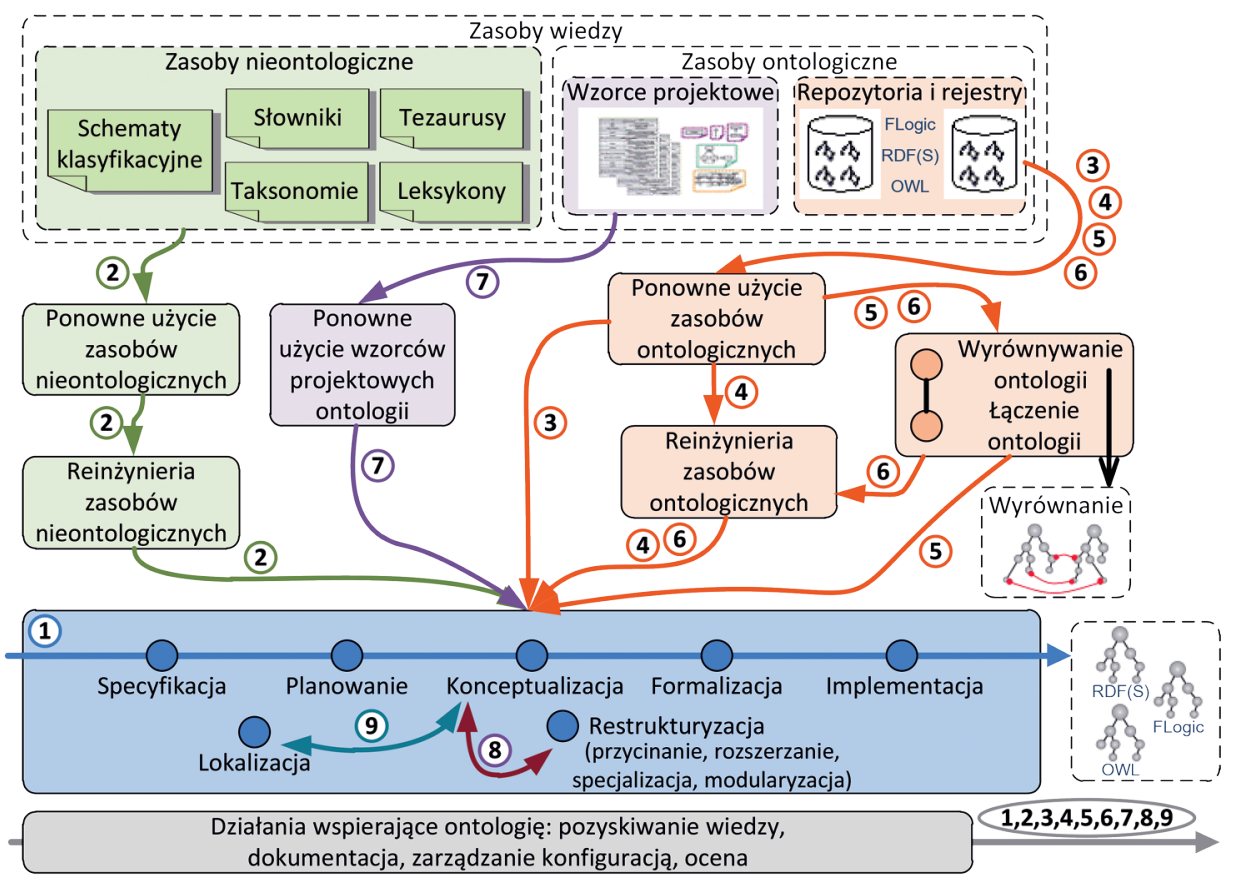

Rys. 2. Mapa scenariuszy budowy ontologii i ich sieci w metodyce NeOn

Źródło: opracowanie własne na podstawie [Suarez-Figueroa 2010].

Metodyka NeOn koncentruje się na opracowywaniu sieci ontologii zamiast pojedynczej ontologii. Sieć ontologii jest tutaj rozumiana jako zbiór ontologii powiązanych za pośrednictwem różnych związków, jak np. mapowanie i wersjonowanie [Casellas 2011]. NeOn zawiera 9 różnych scenariuszy budowy sieci ontologii, a każdy z tych scenariuszy jest oparty na jednym z trzech modeli cyklu życia ontologii. 4-fazowy cykl życia obejmuje etapy: rozpoczęcia, projektu, implementacji i utrzymania. Z kolei cykl 5-fazowy rozszerza model 4-fazowy o etap ponownego użycia zawarty między etapem wstępnym i etapem projektu. Cykl 6-fazowy dodaje etap reinżynierii ontologii po etapie ponownego użycia. Proponowane są również rozszerzenia modeli 5 i 6-fazowego o etap 
łączenia ontologii, zawarty po etapie ponownego użycia ontologii. Ponadto metodyka ta uwzględnia budowę ontologii oraz budowę zespołową, podobnie do metodyk DILIGENT i HCOME [Suarez-Figueroa 2010]. Na rysunku 2 przedstawiono mapę, opisującą zastosowanie poszczególnych scenariuszy zawartych w metodyce NeOn.

Ostatnią omówioną metodyką jest DOGMA, która opiera się na relacjach między aksjomatyzacją dziedzinową i aplikacyjną. Aksjomatyzacja dziedzinowa obejmuje pojęcia $z$ danej dziedziny, a aksjomatyzacja aplikacyjna określa przyczyny i sposoby użycia pojęć dziedzinowych. W metodyce DOGMA wyróżnione są trzy etapy. Etap I jest tzw. fazą przygotowawczą, obejmującą: określenie ogólnych celów ontologii i wymagań użytkowników; identyfikację ekspertów dziedzinowych i źródeł wiedzy oraz przygotowanie studium wykonywalności. Etap II odnosi się do konceptualizacji dziedzinowej i koncentruje się na pozyskiwaniu wiedzy. Z kolei etap III dotyczy specyfikacji aplikacji, a jego elementami są: strukturyzacja, definiowanie pytań kompetencyjnych i ograniczeń semantycznych oraz odpowiadanie na pytania kompetencyjne [Casellas 2011; Spyns i in. 2008].

Tabela 1. Porównanie metodyk projektowania i budowy ontologii

\begin{tabular}{|c|c|c|c|c|c|c|c|c|c|}
\hline Metodyka & $\begin{array}{l}\text { Przezna- } \\
\text { czenie }\end{array}$ & $\begin{array}{l}\text { Formalizm } \\
\text { językowy }\end{array}$ & $\begin{array}{c}\text { Narzędzia } \\
\text { wspierające }\end{array}$ & \multicolumn{2}{|l|}{ Wstęp } & \multicolumn{2}{|l|}{ Budowa } & \multicolumn{2}{|l|}{ Ocena } \\
\hline 1 & 2 & 3 & 4 & \multicolumn{2}{|l|}{5} & \multicolumn{2}{|l|}{6} & \multicolumn{2}{|l|}{7} \\
\hline Cyc & $\begin{array}{l}\text { pozyskiwa- } \\
\text { nie wiedzy }\end{array}$ & CycL & $\begin{array}{l}\text { narzędzia } \\
\text { Cyc }\end{array}$ & - & - & $\begin{array}{l}\text { kodowa- } \\
\text { nie ręczne, } \\
\text { kodowanie } \\
\text { wspomagane, } \\
\text { kodowanie } \\
\text { automatyczne }\end{array}$ & $\mathrm{p}$ & - & - \\
\hline $\begin{array}{l}\text { Metodyka } \\
\text { Gruninge- } \\
\text { ra i Foxa } \\
\text { (TOVE) }\end{array}$ & $\begin{array}{l}\text { indywi- } \\
\text { dualna } \\
\text { budowa } \\
\text { ontologii } \\
\text { częściowo } \\
\text { zależnej od } \\
\text { aplikacji }\end{array}$ & $\begin{array}{l}\text { logika } \\
\text { I rzędu }\end{array}$ & $\begin{array}{l}\text { brak } \\
\text { danych }\end{array}$ & $\begin{array}{l}\text { scenariusz } \\
\text { motywacyj- } \\
\text { ny, pytania } \\
\text { kompeten- } \\
\text { cyjne }\end{array}$ & $\mathrm{s}$ & $\begin{array}{l}\text { formalizacja } \\
\text { terminologii, } \\
\text { formalizacja } \\
\text { pytań kompe- } \\
\text { tencyjnych, } \\
\text { formalizacja } \\
\text { aksjomatów }\end{array}$ & $\mathrm{s}$ & $\begin{array}{l}\text { badanie } \\
\text { komplet- } \\
\text { ności } \\
\text { ontologii }\end{array}$ & S \\
\hline $\begin{array}{l}\text { Metodyka } \\
\text { Usholda } \\
\text { i Kinga } \\
\text { (Enterprise } \\
\text { Model) }\end{array}$ & $\begin{array}{l}\text { indywi- } \\
\text { dualna } \\
\text { budowa } \\
\text { ontologii }\end{array}$ & $\begin{array}{l}\text { języki } \\
\text { modelowa- } \\
\text { nia wiedzy } \\
\text { (np. LOOM, } \\
\text { Ontolingua) }\end{array}$ & $\begin{array}{l}\text { Ontolingua } \\
\text { Server, inne }\end{array}$ & cel budowy & $\mathrm{p}$ & $\begin{array}{l}\text { definiowanie } \\
\text { pojęć i relacji, } \\
\text { kodowanie, } \\
\text { integracja }\end{array}$ & $\mathrm{p}$ & $\begin{array}{l}\text { ocena spe- } \\
\text { cyfikacji, } \\
\text { ocena pytań } \\
\text { kompeten- } \\
\text { cyjnych }\end{array}$ & $\mathrm{p}$ \\
\hline $\begin{array}{l}\text { On-To- } \\
\text {-Know- } \\
\text { ledge }\end{array}$ & $\begin{array}{l}\text { indywi- } \\
\text { dualna } \\
\text { budowa } \\
\text { ontologii } \\
\text { zależnej od } \\
\text { aplikacji }\end{array}$ & dowolny & $\begin{array}{l}\text { OntoEdit, } \\
\text { Onto- } \\
\text { Studio, } \\
\text { KAON, } \\
\text { KAON2 }\end{array}$ & $\begin{array}{l}\text { studium } \\
\text { wykonywal- } \\
\text { ności, } \\
\text { rozpoczęcie } \\
\text { budowy } \\
\text { (określenie } \\
\text { wymagań) }\end{array}$ & S & $\begin{array}{l}\text { rozpoczęcie } \\
\text { budowy } \backslash \\
\text { (słownik, } \\
\text { półformalny } \\
\text { opis } \\
\text { ontologii), } \\
\text { udoskonalanie } \\
\text { (pozyskiwa- } \\
\text { nie wiedzy, } \\
\text { formalizacja) }\end{array}$ & o & $\begin{array}{l}\text { sprawdze- } \\
\text { nie wyma- } \\
\text { gań, } \\
\text { ocena pytań } \\
\text { kompeten- } \\
\text { cyjnych, } \\
\text { testowanie }\end{array}$ & $p$ \\
\hline
\end{tabular}




\begin{tabular}{|c|c|c|c|c|c|c|c|c|c|}
\hline 1 & 2 & 3 & 4 & 5 & & 6 & & 7 & \\
\hline $\begin{array}{l}\text { Methonto- } \\
\text { logy }\end{array}$ & $\begin{array}{l}\text { indywi- } \\
\text { dualna } \\
\text { budowa } \\
\text { ontologii }\end{array}$ & dowolny & $\begin{array}{l}\text { WebODE, } \\
\text { Protégé, } \\
\text { KAON, } \\
\text { OntoEdit, } \\
\text { OntoStudio }\end{array}$ & $\begin{array}{l}\text { planowanie, } \\
\text { specyfikacja }\end{array}$ & $\mathrm{s}$ & $\begin{array}{l}\text { konceptuali- } \\
\text { zacja, } \\
\text { formalizacja, } \\
\text { implemen- } \\
\text { tacja }\end{array}$ & $\mathrm{s}$ & $\begin{array}{l}\text { ocena } \\
\text { ontologii }\end{array}$ & $\mathrm{s}$ \\
\hline DILIGENT & $\begin{array}{l}\text { zespołowa } \\
\text { budowa } \\
\text { ontologii }\end{array}$ & dowolny & $\begin{array}{l}\text { brak } \\
\text { danych }\end{array}$ & - & - & $\begin{array}{l}\text { budowa } \\
\text { ontologii } \\
\text { początkowej, } \\
\text { adaptacja } \\
\text { i modyfikacja, } \\
\text { wprowadze- } \\
\text { nie ustalonych } \\
\text { zmian }\end{array}$ & 0 & $\begin{array}{l}\text { ocena } \\
\text { modyfikacji } \\
\text { użytkowni- } \\
\text { ków }\end{array}$ & o \\
\hline HCOME & $\begin{array}{l}\text { zespołowa } \\
\text { budowa } \\
\text { ontologii }\end{array}$ & dowolny & $\begin{array}{l}\text { brak } \\
\text { danych }\end{array}$ & $\begin{array}{l}\text { specyfika- } \\
\text { cja (zakres } \\
\text { i cele) }\end{array}$ & $\mathrm{s}$ & $\begin{array}{l}\text { konceptuali- } \\
\text { zacja }\end{array}$ & $\mathrm{s}$ & $\begin{array}{l}\text { eksploata- } \\
\text { cja (ocena } \\
\text { i krytyka) }\end{array}$ & o \\
\hline DOGMA & $\begin{array}{l}\text { indywi- } \\
\text { dualna } \\
\text { budowa } \\
\text { ontologii } \\
\text { zależnej od } \\
\text { aplikacji }\end{array}$ & dowolny & $\begin{array}{l}\text { Dogma } \\
\text { Modeler, } \\
\text { Dogma } \\
\text { Studio } \\
\text { Workbench }\end{array}$ & $\begin{array}{l}\text { przygoto- } \\
\text { wanie (cele, } \\
\text { wymagania, } \\
\text { źródła wie- } \\
\text { dzy, studium } \\
\text { wykonalno- } \\
\text { ści) }\end{array}$ & $\mathrm{s}$ & $\begin{array}{l}\text { konceptuali- } \\
\text { zacja } \\
\text { dziedzinowa }\end{array}$ & $\mathrm{s}$ & $\begin{array}{l}\text { specyfika- } \\
\text { cja aplikacji } \\
\text { (pytania } \\
\text { kompeten- } \\
\text { cyjne, ogra- } \\
\text { niczenia } \\
\text { semantycz- } \\
\text { ne) }\end{array}$ & $\mathrm{s}$ \\
\hline $\mathrm{NeOn}$ & $\begin{array}{l}\text { budowa } \\
\text { sieci onto- } \\
\text { logii }\end{array}$ & dowolny & $\begin{array}{l}\text { NeOn } \\
\text { Toolkit }\end{array}$ & $\begin{array}{l}\text { rozpoczęcie, } \\
\text { projekt }\end{array}$ & $\mathrm{s}$ & $\begin{array}{l}\text { projekt, } \\
\text { implemen- } \\
\text { tacja, (ew. } \\
\text { ponowne } \\
\text { użycie, } \\
\text { reinżynieria, } \\
\text { łączenie) }\end{array}$ & $\mathrm{s}$ & utrzymanie & $\mathrm{s}$ \\
\hline
\end{tabular}

' $\mathrm{p}$ ' - zaproponowano elementy danego etapu;

'o' - opisano elementy określonego etapu;

's' - opisano szczegółowo elementy określonego etapu.

Źródło: opracowanie własne na podstawie [Casellas 2011; Gomez-Perez i in. 2004; Fernandez-Lopez, Gomez-Perez 2002; Rajpathak, Chougule 2011; Pinto i in. 2009; Kotis, Vouros 2006; Fernandez-Lopez 1999].

W tabeli 1 zawarto podsumowanie informacji na temat scharakteryzowanych metodyk projektowania i budowy ontologii. Uwzględniono składniki każdej z metodyk, ich poziom szczegółowości, specyficzne cechy oraz wsparcie stosowania danej metodyki przez edytory ontologii. Jeżeli chodzi o etapy zawarte w każdej z metodyk, to określono trzy najważniejsze etapy, tj.: rozpoczęcie projektowania (wstęp), budowę ontologii oraz jej ocenę. Szczegółowość opisu każdego z tych etapów w metodykach oznaczano poprzez symbole „p”, „o", ,s”. Analizując tab. 1, można zauważyć, że poszczególne metodyki różnią się od innych pod względem przeznaczenia, elementów 
składowych i szczegółowości. Część metodyk (DILIGENT, HCOME) dotyczy budowy ontologii w zespołach projektowych, podczas gdy pozostałe koncentrują się na indywidualnym projektowaniu ontologii. Ponadto niektóre służą do projektowania ontologii silnie zależnych od aplikacji, w których będą stosowane (TOVE, On-To-Knowledge, DOGMA). Metodyki różnią się również pod względem ich wspierania przez edytory, przy czym należy pamiętać, że część edytorów ontologii wymienionych w tab. 1 nie jest już dostępna (Ontolingua Server, OntoEdit, KAON, WebODE), a Dogma Studio Workbench jest dostępny na licencji komercyjnej. Ponadto wymienione edytory zazwyczaj wspierają tylko część elementów danej metodyki. Jeżeli chodzi o poziom szczegółowości trzech podstawowych etapów projektowania i budowy ontologii, to za najbardziej szczegółowe można uznać metodyki TOVE, Methontology, DOGMA i NeOn. Metodyki te względnie szczegółowo charakteryzują działania podejmowane w etapie wstępnym projektowania ontologii oraz na etapach jej budowy i oceny.

\section{Dobór metodyki budowy ontologii dla potrzeb zasobów internetowych}

Wybór konkretnej metodyki, która mogłaby zostać wykorzystana w projektowaniu i budowie poszczególnych ontologii dziedzinowych odzwierciedlających zasoby internetowe, powinien być wykonany z uwzględnieniem specyfiki tych ontologii. Analizę stosowalności każdej z metodyk do zadania budowy ontologii poszczególnych zasobów internetowych wykonano z uwzględnieniem specyfiki technologiczno-środowiskowej. Wzięto tutaj pod uwagę przeznaczenie i dopasowanie każdej metodyki oraz jej elementów składowych do postawionego problemu. Zwrócono także uwagę na: łatwość zastosowania każdej z metodyk dzięki klarowności i obszerności opisu jej etapów oraz wsparcie oferowanene przez oprogramowanie służące do budowy i edycji ontologii.

Na wstępie można rozważyć przydatność metodyk przeznaczonych do zespołowego opracowywania ontologii, takich jak DILIGENT i HCOME. W metodyce DILIGENT użytkownicy otrzymują ontologię początkową, modyfikują ją, a następnie na podstawie zmian wprowadzonych przez użytkowników opracowywana jest jej następna wersja. Podobny przebieg ma metodyka HCOME, przy czym w tej metodyce większy nacisk jest położony na wspólne ustalanie przez użytkowników zakresu zmian w nowej wersji ontologii. Metodyki te opierają się na współpracy między użytkownikami biorącymi udział w tworzeniu ontologii. Ontologie poszczególnych zasobów internetowych (np. stron) zostaną opracowane indywidualnie przez inżynierów/specjalistów IT, wobec czego metodyki opierające się na pracy zespołowej nie mają tutaj zastosowania.

Kolejnymi metodykami, nieprzydatnymi w rozważanym obszarze, są Cyc i metodyka Gruningera i Foxa. Metodyka Cyc jest bardzo ograniczona, ponieważ sprowadza się tylko do wprowadzania wiedzy o świecie. Ponadto została ona opracowana na 
początku lat 90. ubiegłego wieku, czyli jeszcze przed rozwinięciem się zastosowań ontologii w informatyce oraz przed upowszechnieniem się sieci Web. W związku z tym metodyka ta nie wykorzystuje standardowych języków budowy ontologii, lecz przeznaczony dla niej język CycL. Ze względu na zastosowanie w niej mało popularnego języka nie jest ona też wspierana przez standardowe edytory ontologii, a jedynie przez specjalizowane narzędzia Cyc. Jeżeli natomiast chodzi o metodykę Gruningera i Foxa, to jest ona oparta na pytaniach kompetencyjnych, które stanowią podstawę do określenia terminologii oraz do oceny ontologii. Metodyka ta nie wykorzystuje do opisu ontologii popularnych języków, jak np. RDF lub OWL, lecz opiera się na logice I rzędu. Wobec tego jej stosowanie nie jest wspierane przez popularne edytory ontologii, a zastosowanie logiki I rzędu może skutkować nierozstrzygalnością ontologii. Należy jednak zaznaczyć, że pytania kompetencyjne są dobrym narzędziem do częściowej oceny ontologii, gdyż badając odpowiedzi ontologii na pytania, można zweryfikować jej kompletność.

Jeżeli chodzi o metodyki On-To-Knowledge i DOGMA, to są one przeznaczone do budowy ontologii zależnych w dużym stopniu od aplikacji, w których będą stosowane. Tymczasem ontologie poszczególnych zasobów internetowych w swojej podstawowej formie nie będą stosowane w żadnych aplikacjach, są one jedynie środkiem do udostępniania wiedzy w standaryzowanej formie. Wobec tego zastosowanie tych metodyk wydaje się niewłaściwe, gdyż zawierają one elementy zbędne dla budowy ontologii w rozważanym obszarze. Oczywiście metodyki On-To-Knowledge i DOGMA zawierają także elementy, których zastosowanie w projektowaniu i budowie ontologii zasobów internetowych jest zasadne. Na etapie wstępnym elementami tymi są: określenie celu, dziedziny i wskazówek projektowych ontologii (np. konwencja nazw) oraz wskazanie pytań kompetencyjnych, kierowanych do ontologii. W etapie oceny ontologii są to następujące elementy: sprawdzenie spójności i poprawności językowej, sprawdzenie spełnienia wymagań i weryfikacja odpowiedzi na pytania kompetencyjne zadawane ontologii.

W metodyce Methontology zawarte są elementy użyteczne w budowie ontologii zasobów internetowych. Takim elementem jest chociażby etap planowania, tzn. ustalenie terminarza prac, ułożenie ich oraz określenie czasu i zasobów koniecznych do ich przeprowadzenia. Podobnie praktycznym elementem jest etap utrzymania ontologii oraz proces wspierający budowę. Dodatkowe elementy metodyki Methontology, których zastosowanie w budowie ontologii zasobów internetowych jest warte rozważenia, to etapy konceptualizacji, formalizacji i implementacji. Zadania zawarte w etapie konceptualizacji są w Methontology opisane bardzo szczegółowo, a dzięki odpowiedniej formie tych zadań model konceptualny jest bardzo łatwy do przełożenia na postać formalną oraz łatwy w implementacji. Ponadto, dzięki wykorzystaniu odpowiedniego edytora ontologii, może być wykonana jednoczesna formalizacja i implementacja.

Podstawową wadą metodyki Usholda i Kinga jest to, że uwzględnione w niej elementy w zasadzie nie są wystarczające do uznania jej za kompletną metodykę. 
Wynika to z faktu, że nie zawiera ona technik, metod i zasad dla uwzględnionych w niej etapów. Dodatkowo nie bierze pod uwagę etapu konceptualizacji, który poprzedzałby etap implementacji, w związku z czym implementacja, przy zastosowaniu tej metodyki, jest wykonywana ad hoc. $Z$ kolei przydatnymi w budowie ontologii zasobów internetowych elementami tej metodyki mogą być: etap identyfikacji celów ontologii i etap jej oceny (ich charakterystyki są zbliżone do charakterystyk fazy specyfikacji wymagań i etapu oceny w metodyce On-To-Knowledge). Interesującym elementem tej metodyki jest też faza zdobywania wiedzy w etapie budowania, polegająca na określeniu pojęć i relacji zachodzących w danej dziedzinie (np.: „kryterium oceny jest klasą”, „klasa o nazwie kryterium zawiera szczegółowe kryteria oceny” itd.).

Jeżeli chodzi o metodykę NeOn, na wstępie można zaakceptować zawarte w niej scenariusze, które wykorzystują cykle życia obejmujące etapy ponownego użycia, reinżynierii i łączenia ontologii. Są to scenariusze od 2 do 7. Ponadto scenariusz 8 koncentruje się na sytuacji, gdy model pojęciowy zawarty w sieci ontologii powinien być skorygowany, a scenariusz 9 dotyczy lokalizacji językowej zasobów ontologicznych. Scenariusze te znajdują więc zastosowanie w budowie ontologii zasobów internetowych. Względnie dobrze dostosowany jest do tego zadania również scenariusz 1, który obejmuje: specyfikację, planowanie, konceptualizację, formalizację i implementację. Jego przebieg jest więc bardzo podobny do etapów rozwoju ontologii zawartych w Methontology, przy czym etapy te są znacznie pełniej scharakteryzowane w Methontology. Ponadto etap specyfikacji występujący w metodyce NeOn jest opisany bardziej szczegółowo niż w Methontology, a obejmuje on m.in.: studium wykonywalności, specyfikację wymagań i pytania kompetencyjne.

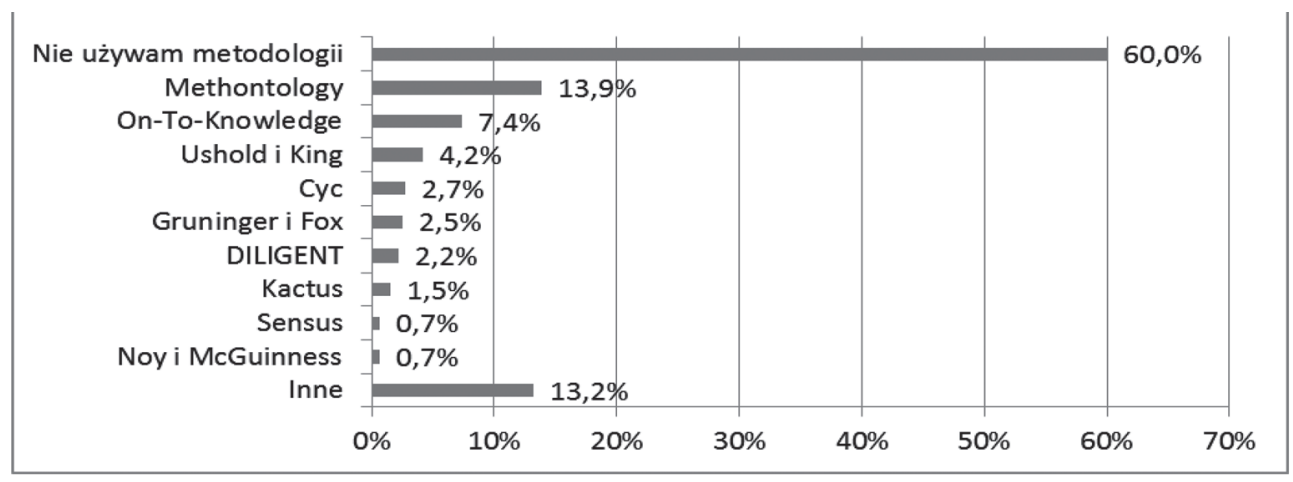

Rys. 3. Wykorzystanie metodologii projektowania i budowy ontologii

Źródło: opracowanie własne na podstawie [Cardoso 2007].

Powyższe rozważania potwierdzają fakt, że każda z przedstawionych metodyk ma jedynie wybrane elementy aplikowalne w rozważanej problematyce. Sytuacja taka obejmuje także inne obszary budowy ontologii dziedzinowych. Przytoczyć tutaj 
można wyniki badania dotyczącego wykorzystania poszczególnych metodyk projektowania i budowy ontologii. Badanie to zostało przeprowadzone w formie elektronicznej na przełomie 2006 i 2007 roku. Uzyskano w nim 627 ankiet, pochodzących od użytkowników list dyskusyjnych: DBWorld, SemanticWeb googlegroups, comp. ai.nat-lang, comp.ai, Music Ontology Specification googlegroups, comp.lang.lisp i semantic-web@w3.org. Wprawdzie badanie to zostało przeprowadzone kilka lat temu, ale od tego czasu nie pojawiła się w literaturze żadna przełomowa metodyka budowy ontologii, która mogłaby podważyć jego wyniki. Wobec tego można uznać je za nadal aktualne. Jego rezultaty zostały przedstawione na rys. 3. Według wyników zawartych na rys. 3, 60\% projektantów ontologii często nie wykorzystuje żadnej spośród istniejących metodyk. Przyczyny tego faktu mogą być dwojakie. Część ontologii jest zapewne projektowana ad hoc w sposób niesformalizowany. Drugą przyczyną takich wyników omawianego badania może być fakt wykorzystywania przez inżynierów ontologii ich autorskich metodyk. Metodyki te najprawdopodobniej charakteryzują się pewnym stopniem sformalizowania, ale różnią się one od formalnych metodyk ujętych w literaturze. Wobec tego należy stwierdzić, że w procesie projektowania i budowy ontologii dziedzinowych nie należy ograniczać się ściśle do jednej konkretnej metodyki projektowania. Wskazane jest zaś często stosowanie różnych metodyk i ich elementów składowych zależnie od specyfiki konstruowanej ontologii dziedzinowej.

\section{Zakończenie}

Podsumowując wykonaną analizę stosowanych metodyk budowy ontologii, można stwierdzić, że znaczna część omówionych metodyk zawiera elementy przydatne przy budowie ontologii poszczególnych zasobów internetowych. W przypadku metodyk: Gruningera i Foxa, On-To-Knowledge, DOGMA, NeOn oraz Usholda i Kinga są to przede wszystkim pytania kompetencyjne, znajdujące zastosowanie podczas oceny skonstruowanej ontologii. Ponadto metodyki Usholda i Kinga, On-To-Knowledge oraz DOGMA mają dobrze zdefiniowany etap wstępny budowy ontologii, obejmujący określenie celu, dziedziny i wskazówek projektowych ontologii. Bardzo przydatna na wstępnym etapie budowy ontologii jest także specyfikacja jej wymagań formalnych, dostarczana przez metodykę NeOn. Z kolei Methontology wyróżnia się wysokim sformalizowaniem etapów konceptualizacji, formalizacji i implementacji ontologii, co jest bardzo pomocne przy jej budowie. Niemniej jednak nie można wskazać jednej metodyki, która byłaby optymalnie dostosowana do wcześniej scharakteryzowanej specyfiki tych ontologii. Wobec tego sugeruje się, aby podczas budowy ontologii zasobów internetowych nie stosować w pełni żadnej istniejącej formalnej metodyki, a zamiast tego skorzystać z wymienionych elementów poszczególnych metodyk.

Dla przedstawionego w artykule problemu budowy ontologii zasobów internetowych najlepszym rozwiązaniem wydaje się zastosowanie podejścia hybrydowego, w pełni uwzględniającego specyfikę tych ontologii. Ponadto podejście to nie powinno 
zawierać elementów zbędnych, niepotrzebnie komplikujących proces projektowania i budowy. Tymczasem w każdej z przeanalizowanych metodyk są takie elementy, zbędne w procesie budowy ontologii zasobów internetowych.

\section{Literatura}

Berners-Lee T., Hendler J., Lassila O., 2001, The Semantic Web. Scientific American, Web Ontology Language OWL Guide Version, http://www.w3.org/TR/owl-guide/ (24.03.2015).

Cardoso J., 2007, The Semantic Web Vision: Where Are We?, IEEE Inteligent Systems, vol. 22, no. 5, s. $84-88$.

Casellas N., 2011, Methodologies, Tools and Languages for Ontology Design, [w:] Casellas N. (red.), Legal Ontology Engineering. Methodologies, Modelling Trends, and the Ontology of Professional Judicial Knowledge, Springer, s. 57-107.

Corcho O., Fernandez-Lopez M., Gomez-Perez A., 2006, Ontological Engineering: Principles, Methods, Tools and Languages, [w:] Calero C., Ruiz F., Piattini M. (red.), Ontologies for Software Engineering and Software Technology, Springer, s. 1-48.

Corcho O., Fernandez-Lopez M., Gomez-Perez A., Lopez-Cima A., 2005, Building legal ontologies with METHONTOLOGY and WebODE, Lecture Notes in Computer Science, vol. 3369, s. 142-157.

Davies J., Studer R., Warren P. (red.), 2006, Semantic Web Technologies: Trends and Research in Ontology-based Systems, Wiley.

Fensel D. (red.), 2003, Ontologies: Silver Bullet for Knowledge Management and Electronic Commerce, Springer-Verlag, Berlin.

Fernandez-Lopez M., 1999, Overview Of Methodologies For Building Ontologies, Proceedings of the IJCAI-99 workshop on Ontologies and Problem-Solving Methods.

Fernandez-Lopez M., Gomez-Perez A., 2002, Overview and analysis of methodologies for building ontologies, The Knowledge Engineering Review, vol. 17, no. 2, s. 129-156.

Gomez-Perez A., Fernandez-Lopez M., Corcho O., 2004, Methodologies and Methods for Building Ontologies, [w:] Gomez-Perez A., Fernandez-Lopez M., Corcho O. (red.), Ontological Engineering, With Examples from the Areas of Knowledge Management, e-Commerce and the Semantic Web, Springer, s. 107-197.

Gruber T.S., 1993, A translation approach to portable ontology specifications, Knowledge Acquisition, vol. 5, no. 2, s. 199-220.

Gruninger M., Fox M.S., 1995, Methodology for the Design and Evaluation of Ontologies, Proceedings of the International Joint Conference on Artificial Inteligence IJCAI95 Workshop on Basic Ontological Issues in Knowledge Sharing.

Hepp M., 2007, Ontologies: State of the Art, Business Potential, and Grand Challenges, [w:] Hepp M., Leenheer P., de Moor A., de Sure Y. (red.), Semantic Web, Semantic Web Services, and Business Applications, Springer, Berlin-Heidelberg, s. 3-22.

Kotis K., Vouros G., 2006, Human-centered ontology engineering: The HCOME methodology, Knowledge and Information Systems, vol. 10, no. 1, s. 109-131.

Kotis K., Vouros G., 2010, Ontological Tools: Requirements, Design Issues and Perspectives, [w:] Poli R., Healy M., Kameas A. (red.), Theory and Applications of Ontology: Computer Applications, Springer, s. 155-173.

Pinto H.S., Tempich C., Staab S., 2009, Ontology Engineering and Evolution in a Distributed World Using DILIGENT, [w:] Staab S., Studer R. (red.), Handbook On Ontologies. Second Edition. International Handbooks on Information Systems, Springer, s. 153-176. 
Rajpathak D., Chougule R., 2011, A generic ontology development framework for data integration and decision support in a distributed environment, International Journal of Computer Integrated Manufacturing, vol. 24, no. 2, s. 154-170.

Shahabi C., Chen Y.S., 2003, Web Information Personalization: Challenges and Approaches, [w:] Goos G., Hartmanis J., van Leeuwen J. (red.), Databases in Networked Information Systems Third International Workshop, Lecture Notes in Computer Science 2822, Springer, s. 1-10.

Smith B., 2003, Ontology, [w:] Floridi L. (red.), The Blackwell Guide to the Philosophy of Computing and Information, Wiley- Blackwell, Oxford, s. 155-166.

Spyns P., Tang Y., Meersman R., 2008, An ontology engineering methodology for DOGMA, Journal of Applied Ontology, vol. 3, no. 1-2, s. 13-39.

Suarez-Figueroa M.C. (red.), 2010, NeOn Methodology for Building Ontology Networks: Specification, Scheduling and Reuse.

Suarez-Figueroa M.C., Gomez-Perez A., Fernandez-Lopez M., 2012, The NeOn Methodology for Ontology Engineering, [w:] Suarez-Figueroa M.C., Gomez-Perez A., Motta E., Gangemi A. (red.), Ontology Engineering in a Networked World, Springer, s. 9-34.

Sure Y., Staab S., Studer R., 2009, Ontology Engineering Methodology, [w:] Staab S., Studer R. (red.), Handbook On Ontologies. Second Edition. International Handbooks on Information Systems, Springer, s. 135-152.

Sure Y., Tempich C., Vrandecic D., 2006, Ontology Engineering Methodologies, [w:] Davies J., Studer R., Warren P. (red.), Semantic Web Technologies. Trends and Research in Ontology-based Systems, Wiley, s. 171-190.

Uschold M., Gruninger M., 1996, Ontologies: Principles, methods and applications, Knowledge Engineering Review, vol. 11, no. 2, s. 93-155. 